\section{Metallogenesis of the Tibetan Collisional Orogen}

\author{
By Zengqian Hou, Nigel J. Cook, \\ and Khin Zaw
}

Ore Geology Reviews

volume 36 October 2009

This Special Issue of Ore Geology Reviews, volume 36 October 2009, presents an overarching, and pioneering, new synthesis of metallogenic provinces in the Himalayan continent-continent collision: a synthesis sweeping in scope and innovative in depth, and as such the first canonical body of knowledge on Himalayan metallogenic systems. Notable are the first quantitative data on porphyry $\mathrm{Cu}-\mathrm{Mo}$ deposits directly linked to the Himalayan orogen, in contradistinction to the traditional view of porphyry deposits forming at continental and intraoceanic convergent margin magmatic settings, with significant implications for exploration.

Conventionally, orogenic belts have been classified as accretionary or continentcontinent in style, each with a distinctive inventory of metallogenic provinces. Accretionary orogens, typified by the MesozoicCenozoic North American Cordillera, Neoproterozoic Altaids of Central Asia, and Neoarchean Kenoran of the Superior Province, involve diachronous accretion of allochthonous terranes across multiple translithospheric sutures. The magmatic arc migrates oceanward through the subductionaccretion complex, magmatism is dominantly juvenile tholeiitic to calc-alkaline, heat input is by magmatism and therefore a clockwise metamorphic P-T-t path, and there is a significant component of transpressional displacement. For the Cordilleran accretionary orogen, mineral deposits of allochthonous terranes, such as porphyry- $\mathrm{Cu}$ (Pebble), Sn-W, and epithermal deposits are incorporated into the orogens, as are VMS (Windy Craggy), and sediment-hosted Pb-Zn deposits (Red Dog), whereas orogenic gold deposits (Mother Lode) develop coevally with accretion and peak metamorphism, and MVT type base metal deposits are sited in foreland basins. In contrast, continent-continent orogens, notably the Cenozoic Himalayan, Meso-Neoproterozoic Grenville, and Paleoproterozoic Trans Hudson of Laurntia involve collision along a single major suture, subdued magmatism ranging from medium- to high$\mathrm{K}$ and shoshonitic series and peraluminous granitoids, heat input by crustal thickening, involvement of passive margin sedimentary sequences, and delamination of overthickened mantle lithosphere. As for accretionary orogens, porphyry- $\mathrm{Cu}$ and other deposits formed in older terranes may be incorporated into continent-continent orogens, but peraluminous granites are more common with their characteristic rare metal deposits. In common with accretionary orogens, MVT-style sedimentary hosted base metal deposits are sited in foreland basins.

The Special Issue takes this conventional view to a whole new level, where metallogenic provinces are set in a sophisticated geodynamic framework that identifies three evolving stages of the Himalayan orogenic belt: main collision during convergence of the Asian and Indian lithospheric plates at 265-41 Ma; late-collisional transform tectonics over $\sim 40-26 \mathrm{Ma}$; and postcollisional extension. Three or more distinctive types of ore deposit are recognised associated with each tectonic stage. This Special Issue stems from a five year integrated strategic research program led by Dr Hou within the framework of Project 973 'Metallogenesis of the Tibetan Collisional Orogen' (2002-2007) of the Ministry of Science and Technology of China. Fourteen papers address various aspects of geodynamics, magmatism, and metallogenesis.

The lead overview paper by Hou and Cook syntheses metallogenic types in the evolving Himalayan geodynamic settings. First stage collisional shortening, initiated at $\sim 65-41 \mathrm{Ma}$, was associated with lithosphere thickening, syn-peak metamorphism, and two magma series: Paleocene-Eocene peraluminous, low- $f \mathrm{O}_{2}$, granitoids derived by crustal anatexis, with associated $\mathrm{Sn}-\mathrm{W}$ rare metal deposits; and Eocene high- $f \mathrm{O}_{2}$ granitoids having skarn related $\mathrm{Cu}-\mathrm{Au}$ polymetallic deposits. As well, there are structurally hosted orogenic gold deposits formed from dilute, $\mathrm{H}_{2} \mathrm{O}-\mathrm{CO}_{2}$ metamorphic fluids. Second stage late collisional transform tectonics, during the Cenozoic at 40-26 Ma, was dominated by left-lateral strike-slip displacement. Potassic 'adakitic' magmatism was emplaced in the transform corridor with associated porphyry $\mathrm{Cu}-\mathrm{Mo}-\mathrm{Au}$ mineral systems. In addition, orogenic gold deposits formed in ductile strike-slip structures; REEbearing mineralization developed in mantle derived carbonatite-alkaline complexes; whereas in the foreland basin $\mathrm{Zn}-\mathrm{Pb}-\mathrm{Cu}-\mathrm{Au}$ deposits are sited in Cenozoic thrust and strike-slip structures. Third stage postcollision tectonics over 25-0 Ma involved the conjunction of delamination of the overthickened mantle lithosphere, with crustal shortening at deep levels but extension at shallower crustal levels. Four distinct oresystems developed during this stage: porphyry $\mathrm{Cu}-\mathrm{Mo}$ deposits associated with high-K 'adakitic' magmas sourced in mafic lower crust; vein type Sb-Au ores sited in the south Tibetan detachment structure and the metamorphic core complex intruded by peraluminous leucogranites; structurally controlled hydrothermal $\mathrm{Pb}-\mathrm{Zn}-\mathrm{Ag}$ ores; and Cs-Au deposits precipitated from 'hotspring' systems where geothermal activity was driven by anatexis of the upper crust.

Papers in this Special Issue address depostis formed before collision, as well as deposits associated with each of the three main stages of the Himalayan orogen. Predating the initiation of collisional orogenesis, there is a range of metallogenic provinces in terranes incorporated into the Himalayan orogen. The Kunlun orogenic belt is located in the northeastern margin of the Qinghai-Tibetan plateau. Feng et al. (2009) report on the Tuolugou $\mathrm{Co} \pm \mathrm{Au}$ stratabound deposit in a metamorphosed sedimentaryvolcanic sequence, sharing many characteristics of clastic sediment hosted $\mathrm{Cu}$ $\mathrm{Co}$ and $\mathrm{Co}-\mathrm{Cu}-\mathrm{Au}$ deposits elsewhere. $\mathrm{Re}-$ Os dating of pyrite yields a $429 \pm 29 \mathrm{Ma}$ isochron in keeping with the Silurian age of the host strata. A complex collisional orogen is preserved at the northern margin of the Qaidam basin, western China. Multiple accretionary orogens occurred, notably in the early Paleozoic and late Paleozoic- early Mesozoic, both having structurally controlled orogenic gold deposits contemporaneous with accretion (Zhang et al., 2009).

At stage one of the Himalayan orogen, Jiang et al. (2009) describe orogenic gold deposits, developed at $\sim 60$ Ma during early collision, in structures parallel to beddingfoliation of Neoproterozoic to Cambrian schists; included is the recently discovered Mayum deposit (> $80 \mathrm{t} \mathrm{Au}$ ) precipitated from low salinity, $\mathrm{H}_{2} \mathrm{O}-\mathrm{CO}_{2}$, metamorphic fluids generated at deeper crustal levels. A few porphyry-type Mo deposits and hybrid $\mathrm{Cu}$ $\mathrm{Au}$ deposits are discovered to be associated with the main-collisional felsic magmas emplaced over 56-40 Ma. Xu et al. (2009) report an early stage of magmatism at $\sim 50$ $40 \mathrm{Ma}$ with coeval development of the 
Xiongcun deposit, telescoped veindisseminated $\mathrm{Cu}-\mathrm{Au}$ and $\mathrm{Au} \pm \mathrm{Ag}$-polymetallic mineralization.

During stage two of the Himalayan orogen, the Mianning-Dechang belt, $270 \mathrm{~km}$ by $15 \mathrm{~km}$ in western Sichuan, developed in the eastern Indo-Asian collision zone. This belt is known for carbonatite-alkaline complexes emplaced over 40-10 Ma. Hou and coworkers describe the tectonic setting, magmatism, and age of REE deposits. The intrusions and associated magmatichydrothermal REE mineralization were controlled by large scale Cenozoic strikeslip faults in a transform setting that evolved from transpressional to transtensional displacement. Notable is the giant Maoniuping and several smaller REE deposits (Hou et al., 2009c; Xie et al., 2009). The Ailaoshan belt, Yunnan, contains one of the largest gold resources in China. Sun et al. (2009) present detailed isotope geochemistry on the Daping deposit, a quartz vein system hosted in diorites. Ores formed under granulite facies conditions from dominantly metamorphic hydrothermal fluids carrying a mixed mantle and crust signature; metamorphism was induced by upwelling asthenosphere magmas triggered by delamination. During this stage, but outboard of the main collision zone, in the Lanping foreland basin and foldbelt, economic deposits of $\mathrm{Zn}-\mathrm{Pb}-\mathrm{Cu}-\mathrm{Ag}$ were precipitated in a regional thrust duplex. These ores formed from basinal brines, and share some features in common with "classic" sedimentary-hosted base-metal deposits, but may be a new sub-class of such deposits in terms of the thrust control and range of metal budgets (He et al., 2009).

For stage three of the Himalayan orogen, several papers address the mid-Miocene Gangdese orogenic belt in southern Tibet, a $400 \mathrm{~km}$ by $50 \mathrm{~km}$ belt where mid-Miocene monzogranite and quartz monzonite stocks of high-K calc-alkaline to shoshonitic magma series intruded a terrane of MesozoicCenozoic batholiths and surrounding Triassic-Tertiary volcano-sedimentary sequences of the Lhasa terrane. During the main collisional event at $\sim 60-50$ Ma mafic magmas underplated and assimilated the crust, and were subsequently remelted during extensional crustal collapse by upwelling asthenosphere. The main porphyry province defines a spectrum from $\mathrm{Cu}-\mathrm{Mo}$ to skarn-type $\mathrm{Pb}-\mathrm{Zn}$ mineralization associated with intrusive stocks aged 19-11Ma (Hou et al., 2009; Qu et al., 2009), including the newly discovered Qulong deposit (Yang et al., 2009). At the same stage, but in the east- west trending structural thermal dome related to the south Tibetan detachment system, intruded by mid-Miocene peraluminous leucogranites, numerous $\mathrm{Sb}-\mathrm{Au}$ deposits are distributed around the thermal dome. There is a radial distribution of metal budgets from $\mathrm{Au}$, through $\mathrm{Sb}-\mathrm{Au}$ to $\mathrm{Sb}$ away from the domes (Yang et al., 2009). Also in the Miocene are coal seams of the Bangmai Formation deposited in a basin above Ge-rich granite batholiths emplaced in the middle Triassic. Where fault intersections cross-cut organic rich coal seams Ge orebodies formed, enriched as well in $\mathrm{Nb}, \mathrm{Li}, \mathrm{Sb}, \mathrm{W}, \mathrm{Bi}, \mathrm{U}$, and HREE, precipitated from basinal brines that advected into the underlying granite ( $\mathrm{Hu}$ et al., 2009).

In summary, this Special Issue is the forefront of knowledge in metallogenesis of the Himalayan orogenic belt; accordingly, it will impel progress in the science of metallogeny by promoting understanding of metallogenic systems in continent-continent collisional orogens.

\section{Robert Kerrich}

University of Saskatchewan,

Saskatoon,

Canada S7N 5E2

E-mail: robert.kerrich@usask.ca

\section{Professor Manuel Carlos Serrano Pinto (1936-2011)}

It was with regret that the IUGS Executive Committee (EC) learned that Professor Manuel Carlos Serrano Pinto, INHIGEO's past-President (2000-2004), passed away on 15 January 2011.

Professor Pinto was Professor at the University of Aveiro, Portugal, where his main research fields were on Geochemistry and Isotope Geology and History of Geology and Mining. His research topics were on geochemistry, petrology and geochronology of granitoids, environmental geochemistry, geochemical exploration and history of geology and mining in Portugal and Brazil.

His involvement with the history of geology and mining led him to be an active member of the IUGS Commission on the History of Geology (INHIGEO), where he served as President from 2000 to 2004. In relation with these activities he published a series of papers and co-organized four Luso-Brazilian international conferences on the History of Science (2001-2011).

The IUGS acknowledges with thanks the contribution of Professor Pinto to the history of the geosciences, to INHIGEO and IUGS, and expresses its tribute to his memory. 